\title{
Introducing the Technological Pedagogical Content Knowledge (TPACK) Framework to the University of Santo Tomas Faculty of Medicine and Surgery

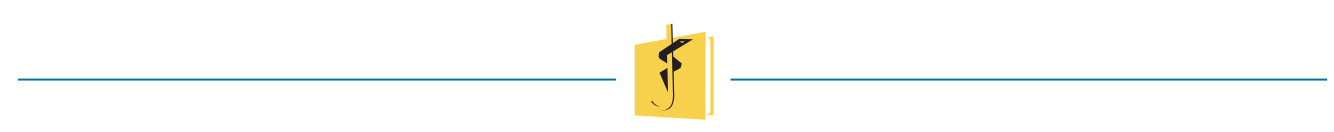

\section{Remedios Dee-Chan, MD, MHPEd}

Technological developments affect both teaching and learning. The inclusion of educational technologies provides a tremendous boost and motivation in knowledge acquisition of the millennial, tech-savvy students much like our University of Santo Tomas Faculty of Medicine and Surgery (USTFMS) medical students. Technological Pedagogical Content Knowledge or TPACK is the buzzword for this novel approach. Its goal is to create an effective learning environment for students and more importantly, TPACK is essential in the preparation of the outcomes-based curriculum of the doctor of medicine (MD) program.

The TPACK framework demonstrates the relationship between three knowledge areas namely: technology, content, and pedagogy. In Lee S. Shulman's 1986 work "Those Who Understand: Knowledge Growth in Teaching", he discussed that teachers possess specific knowledge about the subject matter they are teaching or content knowledge (CK) and a set of knowledge about how to teach the subject matter or pedagogical knowledge (PK). Schulman mentioned

Remedios Dee-Chan

mmrdchan@yahoo.com

Medical Education, Faculty of Medicine and Surgery,

University of Santo Tomas, Manila, Philippines that effective teachers overlap these two knowledge sets and thus coined the term pedagogical content knowledge (PCK).[1] Mishra and Koehler in 2006 noted that the biggest change happening in education is the use of technology in the classroom (TK). However, they observed that TK was treated "outside of and unconnected to PCK". [2] Thus in 2011, they created a new framework, TPACK, which "adds technology to pedagogical content knowledge and emphasizes the connections, interactions, and constraints that teachers work with in all three of these knowledge areas".[3]

The TPACK framework is represented by a Venn diagram. The circles represent $C K, P K$, and TK. The areas where the circles' overlap are:

1. Pedagogical Content Knowledge (PCK): It is the knowledge that teachers have about their content and the knowledge that they have about how to teach that specific content as identified by Shulman. [1] It is exemplified by the different teaching strategies used by faculty members teaching basic science courses or clinical courses. PCK enables teachers to use the most effective methods for teaching the specific content subject matter.

2. Technological Pedagogical Knowledge (TPK): It is the set of skills developed by teachers to identify the best technology to support a particu- 


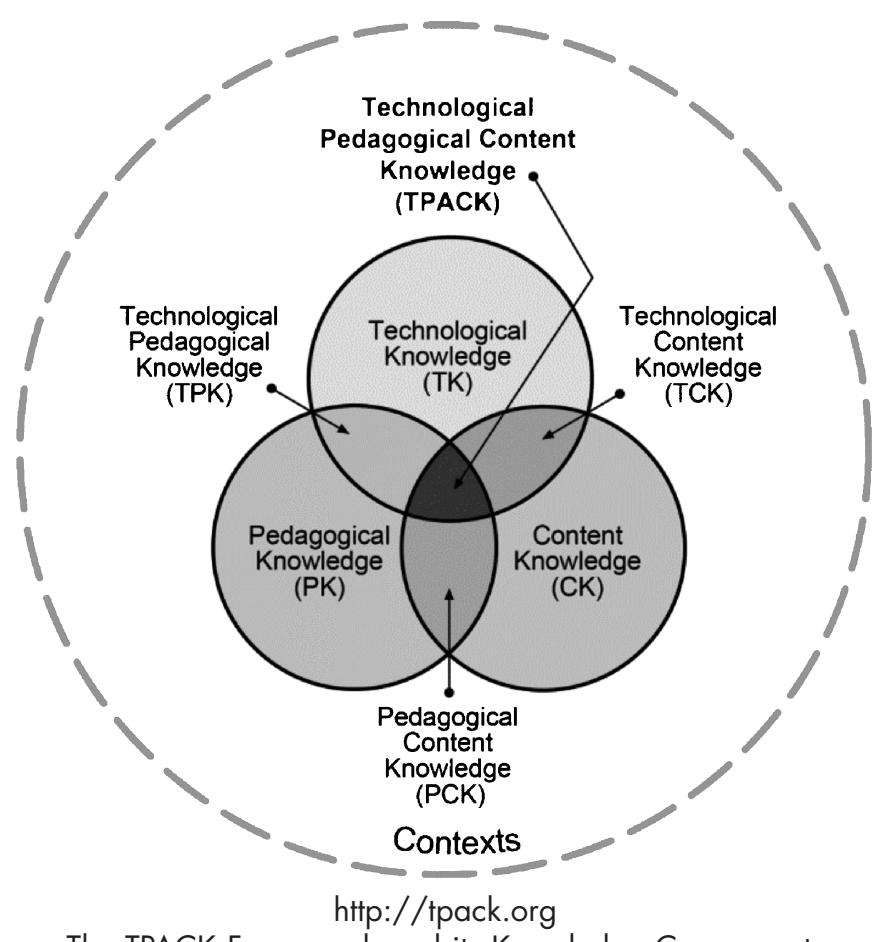

The TPACK Framework and its Knowledge Components

lar pedagogical approach.[4] For example, making students work in collaborative groups (pedagogy) and having them communicate what they have learned in a multimodal presentation using PowerPoint, Prezi, Keynote or other digital tools.

\section{Technological Content Knowledge (TCK):}

It is the set of skills that teachers acquire to help identify the best technologies to support their students as they learn content. [4] For instance, if the teacher wants the students to learn, reply, and apply information on a module on disaster risk reduction, students are instructed to watch or view uploaded online videos and respond to guide questions or tasks.

In the center of the diagram is the TPACK framework which refers to the knowledge required by teachers for integrating technology into their teaching in any content area.[5] Teachers have an intuitive understanding of the complex interplay between the three basic components of knowledge (CK, PK, TK) by teaching content using appropriate pedagogical methods and technologies.

Is USTFMS ready for the TPACK? The PCK segment is well-established in the USTFMS outcomes-based curriculum through a series of faculty workshops. However, the level of TK and subsequently TPK and TCK needs to be expanded to all faculty ranks. Jimoyiannis (2010) acknowledged the need for effective teacher preparation as "an important factor in the successful integration and sustainability of information and computer technology (ICT) in education". [6] Once our USTFMS faculty members possess sufficient TPK and TCK, the creation of instructional designs displaying the entire TPACK framework will lead to the creation and development of a holistic curriculum that will provide the best learning environment for our students. 


\section{REFERENCES}

1. Shulman L. Those who understand: Knowledge growth in teaching. Educational Researcher. 1986;15(2):4-14.

2. Mishra P, Koehler M. Technological pedagogical content knowledge: A framework for integrating technology in teachers' knowledge. Teachers College Record. 2006; 108(6): 1017-54.

3. Harris JB, Hofer, M. Technological pedagogical content knowledge in action: A descriptive study of secondary teachers' curriculum-based, technology-related instructional planning. JRTE. $2011 ; 43(3): 211-29$.

4. Kurt S. Technological Pedagogical Content Knowledge (TPACK) framework. iJET [internet]. 2018 May [cited 2019 Oct 29]; Available from: https://educationaltechnology. net/technological-pedagogical-content-knowledge-tpackframework/.

5. Mishra P, Koehler M. Technological Pedagogical Content Knowledge (TPCK): Confronting the wicked problems of teaching with technology. In: Carlsen R, McFerrin K, Price J, Weber R, Willis D eds., Proceedings of SITE 2007 Society for Information Technology \& Teacher Education International Conference (pp. 2214-26). San Antonio,
Texas, USA: Association for the Advancement of Computing in Education (AACE). [internet]. 2007 [cited 2019 Oct 31]; Available from: https://www.learntechlib.org/ primary/p/24919/.

6. Jimoyiannis A, Gravani M. Exploring adult digital literacy using learners' and educators' perceptions and experiences: The case of the second chance schools in Greece. Journal of Educational Technology and Society. $2011 ; 14(1): 217-27$.

(c) Open Access This article is licensed under a Creative Commons Attribution 4.0 Internationa License, which permits use, sharing, adaptation, distribution and reproduction in any medium or format, as long as you give appropriate credit to the original author(s) and the source, provide a link to the Creative Commons license, and indicate if changes were made. The images or other third party material in this article are included in the article's Creative Commons license, unless indicated otherwise in a credit line to the material. If material is not included in the article's Creative Commons license and your intended use is not permitted by statutory regulation or exceeds the permitted use, you will need to obtain permission directly from the copyright holder. To view a copy of this license, visit http://creativecommons.org/licenses/by/4.0/. 